\title{
ESG Disclosure in an Emerging Market: An Empirical Analysis of the Influence of Board Characteristics and Ownership Structure
}

\author{
Jaime F. Lavin ${ }^{1, *(D)}$ and Alejandro A. Montecinos-Pearce ${ }^{2}$ (D) \\ 1 Escuela de Negocios, Universidad Adolfo Ibáñez, Av. Diagonal Las Torres 2700, Santiago 7941169, Chile \\ 2 Escuela de Negocios, Universidad Adolfo Ibáñez, Av. Padre Hurtado 750, Viña del Mar 7561046, Chile; \\ amontecinos@uai.cl \\ * Correspondence: jaime.lavin@uai.cl
}

check for updates

Citation: Lavin, J.F.; MontecinosPearce, A.A. ESG Disclosure in an Emerging Market: An Empirical Analysis of the Influence of Board Characteristics and Ownership Structure. Sustainability 2021, 13, 10498. https://doi.org/10.3390/ su131910498

Academic Editor: Mihajlo

(Michael) Jakovljevic

Received: 6 August 2021

Accepted: 18 September 2021

Published: 22 September 2021

Publisher's Note: MDPI stays neutral with regard to jurisdictional claims in published maps and institutional affiliations.

Copyright: (c) 2021 by the authors. Licensee MDPI, Basel, Switzerland. This article is an open access article distributed under the terms and conditions of the Creative Commons Attribution (CC BY) license (https:/ / creativecommons.org/licenses/by/ $4.0 /)$.

\begin{abstract}
In the context of greater demand for corporate transparency, there is a growing pressure on boards to produce and communicate information to their investors and stakeholders. The current literature on integrated reporting shows that the provision of ESG information is a crucial factor that improves corporate governance by reducing agency problems. This issue is also critical in emerging economies, and particularly among Latin American firms. The concentration, opacity, and lack of evidence about ESG disclosure in less developed financial markets provide a promising environment to study the implications of board heterogeneity and ownership structure on strategic corporate decisions such as the disclosure of ESG indicators in developing economies. Using Tobit panel data models, we study how these factors affect the extent of ESG disclosure by Chilean listed firms. Our main results suggest that a board's independence and gender diversity positively influence the extent of disclosure of ESG indicators. Our evidence helps firms concerned with strengthening their board's features, investors that require screening firms' ESG risk factors, and supports regulators' decisions on setting norms regarding the extent of disclosure of ESG information by firms.
\end{abstract}

Keywords: environmental, social and governance disclosure; developing countries; Latin America; listed firms

\section{Introduction}

In recent decades, the world has changed. As many privately owned firms produce revenues greater than the GDP of many countries [1], the rise in the access of the general public and institutional investors to information about the environmental and social consequences of a firm's decisions as well as the availability of information about a firm's governance has spurred stakeholders' relevance in management decisions. More empowered citizens, public institutions, and investors demand more transparency and accountability from firms. Thus, the scrutiny of the stakeholders is not just over what firms produce, but also on how they do it. In this context, the value created by the firm has gone beyond the impact of the bottom line. Moreover, the sustainability of short-run returns now depends on a broader range of variables as global investors increase their awareness of the existence of more sources of risk to the firm. Hence, the widening influence, the scope, the impact, and the visibility of the operation of listed firms, beyond the mere generation of profits, uncover a new margin of risks exposure [2,3].

The latter risks stem from an ever-expanding demand for firm accountability as implied by the concepts of stakeholder capitalism and stakeholder economics. From the perspective of the legitimacy theory, ESG disclosure (ESGD) mitigates firm-specific risks [4], which at least theoretically, should help to reduce their weighted average cost of capital, thereby improving firm performance (FP). Using data from international listed firms belonging to the S\&P 1200 Global Index, Raimo, Caragnano, Zito, Vitolla, and Mariani [5] 
find a negative relation between ESGD and the cost of debt. Similarly, Raimo, de Nuccio, Giakoumelou, Petruzella, and Vitolla [6] evidence a negative relationship between ESGD and the cost of equity capital among international listed firms operating in the food and beverage sector. This evidence reaffirms that at least from the financial dimension ESG impact is relevant.

According to a study by McKinsey Quarterly [7], attending to environmental, social, and governance (ESG) concerns often increase firm value for five reasons. First, ESG compliance has a positive effect on the top-line growth by opening new markets and expanding income in current markets; second, keeping track of ESG performance reduces costs by lowering energy consumption and reducing water intake; third, by achieving greater strategic freedom as self-regulation, ESG deters governmental regulation, as well as increasing the chances of obtaining subsidies and gaining other governmental support; fourth, a strong ESG proposition boosts employee motivation and productivity as social credibility increases; and finally, ESG enhances investment return by improving the allocation of capital in the long term.

Recent evidence from the literature suggests there is a link between ESGD and different dimensions related to FP. For instance, using UK data Albitar, Hussainey, Kolade, and Gerged [8] study the moderating role of governance mechanisms on the relation between ESGD and firms' financial performance. Similarly, Cordazzo, Bini, and Marzo [9] investigate the influence of the implementation of the EU Directive on non-financial information on the relevance of non-financial information on the value of a firm. Some studies examine the relationship between financial FP and ESGD beyond the scope of developed economies. Using data from the Bombay Stock Exchange, Sharma, Panday, and Dangwal [10] find a positive relationship between Profitability/ROA and ESGD.

ESG disclosure also has effects on corporate sustainability. For instance, studying Asian firms, Alsayegh, Rahman, and Homayoun [11], find evidence that a good performance in terms of disclosing the implementation of environmental and social strategies, strengthens corporate sustainability performance. As stakeholders exert pressure on firms for having a more sustainable behavior and a lower impact on society and the environment, adequate ESG behavior and proper disclosing policies become a key element of sustainability through adequate disclosure policies $[12,13]$. These works highlight the impact of ESGD spreading beyond the borders of the firm, positively improving the social value created by corporations as well.

In response to the above, boards across the world strive to improve the generation and provision of information about ESG performance for their stakeholders. These efforts provide a range of effects ranging from the ability to manage the firms' assets and optimize ESG achievement to communicating a more comprehensive view of firm performance to both external (customers, government, community, etc.) and internal stakeholders (shareholders, workers, etc.). In this context, ESGD is often assumed to operate as a complementary control mechanism to the existence of boards that aim to reduce agency costs among stakeholders [14], thereby increasing the efficiency of a firm's operation. In addition, in the finance literature, it is widely acknowledged that in exchange for their investment, shareholders receive dividends and control rights over the firm [15]. These control rights are exercised through board members. Hence, the characteristics of the board as a whole reflect the fundamental aggregated preferences of the shareholders. As long as there is a divergence between the aggregated board's and top management's preferences, which gives rise to agency problems, the board may have an impact on the existence and quality of ESGD. In this regard, there is evidence that voluntary disclosure depends on the number of non-executive board members [16]. There is also evidence on how board characteristics affect the quality of a company's disclosure [17].

Although in recent years the quality of ESGD has attracted more attention, most of the evidence comes from developed economies. Therefore, the determinants of the extent of ESGD in emerging markets continue to be scarcely studied [3]. However, these markets, and particularly Latin American markets, provide a promising environment to 
analyze the implications of board heterogeneity on strategic corporate decisions. This occurs because the legal systems and corporate governance regulations, coupled with the recent eruption of ESG concerns in these markets, provide a less restricted environment to study the mechanisms that boards may use to mitigate the agency problem, particularly in a novel, prominent, and evolving area such as ESG performance in emerging countries. Developing economies' less regulated setting also implies fewer restrictions on board characteristics [18], which also vary through time, providing favorable conditions to assess how those characteristics affect strategic corporate decisions. For instance, La Porta et al. [19] find that legal enforcement in developing countries influences the ability of firms to raise capital.

Another relevant peculiarity of emerging markets is the rising relevance of the involvement of institutional investors on firms' decisions. They provide the main entrance of minority shareholders to Latin American boards; hence, they generate a connection between firms and the general public's preferences. Thus, the presence of institutional investors on Latin American corporate boards [20] in recent years provides another source of board heterogeneity that could shed light on the mechanisms that determine firms' strategic decisions. The shortage of evidence on ESGD in Latin America, combined with the distinctive attributes of the business environment of this region, prevents a direct extrapolation of the evidence obtained from developed countries [3].

In light of the foregoing, we contribute to the ESG literature by empirically studying the relationship between the extent of a firm's ESGD and the ownership structure and characteristics of the board in a dynamic Latin American financial market such as Chile. In addition to the firm's ownership structure, some of the features that we consider to describe boards are the independence and diversity of their members. The Chilean financial market exhibits a combination of high-quality granular financial data combined with the characteristic features of emerging markets' legal systems, lack of corporate governance regulations, and relevant institutional investors. Moreover, Chile is a member of the OECD (Organization for Economic Co-operation and Development), which implies that the country possesses high-quality and extensive availability of economic and financial data. Therefore, the Chilean market provides conditions that enables us to properly analyze the ESGD phenomenon in an emerging economy

We conducted the analysis using a panel-data Tobit regression for 2015-2019. To address our research question, we followed a three-step procedure. First, we studied, one at a time, if ownership, independence, and diversity contribute separately to explaining the evolution of ESGD indices. Second, we considered ownership, independence, and diversity jointly to study the evolution of ESGD indices. Finally, having analyzed the statistical significance of each dimension in a simultaneous way, we continued to study them but in an isolated form, applying robustness tests. We ultimately seek to deepen the understanding of the mechanisms of how board characteristics and ownership structures contribute to explaining the evolution of ESGD quality of companies in developing countries.

This paper contributes to the discussion of ESG criteria adoption and ESG performance disclosure in several ways. First, this study sheds light on the general understanding of the eruption and implementation of the ESGD phenomenon in emerging markets. Second, our work helps regulators of emerging economies who wish to address and refine legal frameworks to enhance the sustainable generation of profits based on relevant ESG information. Finally, this research provides helpful information to firms as they strive to adapt to important environmental and social changes that add new complexities to their strategic management and businesses administration.

In Section 2 of this paper, we review the prior research and develop the hypotheses. In Section 3, we present the methodology, data, sample, and empirical strategy. Section 4 presents the analysis, results, and discussion; and Section 5 presents the conclusions of our study. 


\section{Theory and Hypotheses}

The voluntary disclosure of a firm's environmental, social, and corporate governance performance depends on many factors. The cultural environment in which firms operate coupled with corporate governance practices and regulations, ownership structure, as well as company and board characteristics, are relevant elements to consider in explaining the ESGD decision of modern companies. Nowadays, ESGD provides stakeholders with valuable data to assess the firm's level of exposure to ESG risks and to monitor their ability to manage these non-financial sources of risk [2,3]. In addition, ESGD impels the transparency of firms that face a growing demand to reduce the opacity of their operations and their real impact on society, the environment, and governance. Therefore, ESGD enables firms to confront the voracious demand for information that investors need to properly assess their investment processes based on responsible investment criteria [21].

Accordingly, this global phenomenon, that pushes markets, firms, managers, and stakeholders towards major transparency, accountability, and market discipline, is not alien to Latin American firms that increasingly experience this latter (ESG) demand for information. However, similar to other emerging markets, and in contrast to developed markets, Latin American ones suffer from a scarcity of studies that empirically explore the mechanisms that explain the ESGD behavior of firms [22,23]. This lack of empirical evidence on ESGD in Latin America, combined with the characteristics of the Latin American political economy, prevents a direct extrapolation of the evidence about the mechanisms that drive ESGD in developed countries. For instance, as Husted and Sousa-Filho [3] indicate, the institutional context of Latin America should change some of the relationships between board structure and ESGD ordinarily observed in the literature. We contribute to the extant literature by providing new empirical results concerning the factors that influence the quality of the ESGD behavior of listed firms in emerging markets.

\subsection{Corporate Governance in Emerging Markets}

Transparency is a relevant factor in the corporate governance of firms. This occurs because the transparency of a firm directly impacts the firm's value and performance over time. As the financial literature states, in a frictionless world, the value of a company mainly depends on the cash flows it generates and the associated risks. However, the existence of opportunistic behavior from the firm's controlling groups coupled with a weak protection of minority shareholders' property rights, and new sources of risk-such as those derived from ESG aspects-become relevant elements in the investors' decision-making and the valuation process of firms [24]. The ubiquity of these elements is widespread in emerging markets and Latin America [25].

The relevance of property rights for investors is based on the existence of rules and laws that provide adequate protection to minority investors and in the degree of application of regulations and laws in the countries where assets are issued. The differences in the quality of laws and their legal enforcement, explain the ability of firms to raise capital and the willingness of investors to finance them. A direct consequence of the latter are the differences between countries with respect to the capital structure of firms and their level of ownership concentration [4]. Consequently, the legal protection of investors and the enforcement of the law plays a crucial role in how companies raise funding, their cost of capital, and how shareholders participate in their property [26].

The legal origin of countries explains the differences in legal protection of investors and the enforcement of the law between countries. La Porta et al. [26] show that civil law countries protect investors less, whereas common law countries provide greater protection. Similarly, the quality of law enforcement in common law countries is greater than in civil law ones. Consequences of the aforementioned reveal that compared with countries with high investor protection, among countries with lower investor protection there are a greater concentration of company ownership [26], lower stock valuations [27], less access to external financing [28], lower equity market liquidity [29], and less financial development [30]. 
The relevance and merit of sound corporate governance practices among firms, especially among emerging markets, is apparent since there is evidence of expropriation behaviors by controlling shareholders [31]. As the financial literature shows, advancements in corporate governance that improve the legal protection for shareholders, are beneficial to firms, especially in emerging country contexts. On the one hand, greater access to financing reduces the cost of capital, improves performance, and favors better treatment for all stakeholders. On the other, it strengthens a better allocation of resources in the economy with the consequent positive effect on the financial development and growth of countries [32-36].

These insights are especially relevant in the Latin American context. Despite the paucity of literature, the evidence suggests that compared to developed markets, Latin American markets are characterized as having limited financial development, less access to external financing, highly concentrated ownership structures of firms, and low participation of institutional investors in the ownership of listed firms [33]. In this sense, these markets are quite similar to other developing countries. Regional firms' corporate governance must face a high concentration of firm ownership in the hands of business groups, reduced legal protection of property rights, and weak legal enforcement. Overall, these elements affect the corporate structure of the firms and generate agency problems between controllers and the rest of the stakeholders [37].

The existence of controlling business groups in emerging markets is a widespread phenomenon with ample effects on the behavior of firms. In particular, the affiliation of a firm to an economic group greatly affects the firm's behavior regarding corporate social responsibility (CSR) factors [31]. This phenomenon is present in Latin American firms. Moreover, according to the OECD [38], economic groups need to improve their communication with their stakeholders, with transparency and disclosures being key challenges for Latin American groups.

Thus, in the Latin American context, the implications of the aforementioned factors for voluntary disclosure are strong. For instance, Correa-Garcia et al. [25] find that control concentration negatively affects the quality of voluntary disclosure while foreign ownership, the age of the business group, and board size help business groups to improve their voluntary disclosure practices. In addition, the quality of ESGD for Latin American firms is a relevant topic for corporate governance practices because voluntary reports fulfill a dual role of disclosure and signaling to the market their environmental, social, and governance commitments [39-41]. This dual role is idiosyncratic to the Latin American (and emerging) economies because, compared with developed markets, Latin American markets operate under more opacity, so companies need to provide signals about their ESG commitments.

\subsection{Board, Ownership and Firm Characteristics}

The voluntary disclosure behavior of firms has attracted ample interest mainly in developed countries and to a lesser extent in developing ones. Both theoretically and empirically, different studies address the widespread debate about the impact on voluntary non-financial disclosure of the activity and diversity of the board, the ownership structure of the firm, and the characteristics of the firm. The main results of these studies indicate that some of the drivers of voluntary disclosures in developed countries also apply to developing ones; however, there are important differences among the determinants between the two kinds of countries [42]. In general terms, these findings show that board characteristics and ownership structure have more influence on the occurrence, quality, and extent of voluntary disclosure than company characteristics.

Boards of directors play an important role as a corporate governance mechanism. Implementing policies of stakeholder engagement and good practices of corporate social responsibility, boards balance the interest of all stakeholders in an accountable way $[43,44]$. More importantly, if there is a complementarity between the board and transparency, then boards foster the disclosure of information [17]. Moreover, in the event of agency problems, the board is one of the main control mechanisms that shareholders use to 
mitigate the intensity of agency costs. In this sense, voluntary disclosure performs the role of a control mechanism for two agency relationships: (i) between shareholders and other stakeholders [45,46], and (ii) between the shareholders and the firm's management [14].

Several studies analyze how the strength of the board determines the existence and quality of the disclosed information through which boards reduce asymmetries of information between managers, owners, and the remaining stakeholders [14,16]. Building on the assumption of complementarity between the role of the board in mitigating the agency problem and firm transparency, Jensen and Meckling [47], Donelly and Mulcahy [16], and Frías-Aceituno et al. [14] test the existence of a positive relationship between a board's strength (measured by its size, independence, activity, and diversity) and the existence and quality of voluntary disclosure. The evidence shows a positive relationship between size, fraction of non-managerial directors on the board (independence), and diversity of the board and voluntary disclosure (presence and quality depending on the study).

More recently, some studies have documented the significance of the diversity of the board and senior executives on the behavior of ESGD. These studies define diversity as the dissimilarity of the characteristics of board members-for instance, gender or nationality-and find that more diverse boards have greater problem-solving abilities, are more effective in their leading roles, and are better at establishing global relations for the firm [48]. Moreover, the evidence shows that gender diversity positively influences firm behavior [49,50]; and promotes greater information transparency [51,52]. In addition, the diversity of a board also affects the corporate governance model used by the firm. For instance, empirical evidence suggests that promoting board diversity enhances the stakeholders' engagement by positively impacting the voluntary provision of global information by firms [14]. Recently, some studies have expanded the scope and impact of diversity beyond the board to senior management. For instance, Ouni et al. [53] find empirical support for the beneficial effect of gender diversity at the board and senior management levels in financial, social, and environmental terms among Canadian firms.

Ownership structure and shareholder characteristics are other elements that affect voluntary disclosure. This is especially relevant in contexts of information asymmetries, since some shareholders may have the skills, motivation, and knowledge to prevent the concealment of information and to increase the quality and extent of disclosure [16]. Similarly, some ownership structures could affect the level of information asymmetry present in different company contexts [54]. For instance, analyzing the role of ownership structure characteristic on the integrated reporting policies among listed international companies, Raimo et al. [54] find a positive effect of institutional ownership on the quality of integrated reports along with a negative effect of ownership concentration, managerial ownership, and state ownership. These results show how the different ownership structures influence the disclosure policies that affect corporate communications between firms and their stakeholders.

Similar results stand at the emerging market level. For instance, studying voluntary disclosure of listed firms in China, Huafang and Jianguo [55] find that higher blockholder ownership and the participation of foreign shareholders are positively related to increased disclosure. However, they do not find a relationship between disclosure and managerial ownership, state ownership, and legal-person ownership. Similarly, an increase in independent directors raises corporate disclosure, whereas CEO duality is associated with lower disclosure. They also state that larger firms have greater disclosure, while firms with growth opportunities are reluctant to disclose information voluntarily.

The influence on voluntary disclosure of corporate governance, ownership structures, and the characteristics of firms have also been studied in some emerging market countries in the Commonwealth. For instance, Barako et al. [56] analyze the behavior of listed Kenyan firms, finding that positive drivers of voluntary disclosure are the existence of an audit committee and the existence of independent non-executive directors. They also evidence that two ownership structures influencing voluntary disclosure are the proportion of foreign ownership and the percentage of stock owned by institutional investors. 
Finally, they document that size and financial leverage are attributes positively related to voluntary disclosure.

Notwithstanding the aforementioned, there is still controversy regarding the positive or negative impact of the previously mentioned factors on voluntary disclosure [14]. For instance, analyzing the role of non-executive directors, some studies find a direct relationship between the presence of non-executive directors and disclosure [57,58], while others report an inverse relationship [52,59] or none at all [60]. These examples emphasize the possibility of variation in the mechanisms that determine ESGD depending on the characteristics of the market and their culture, highlighting the danger of generalizing conclusions about ESGD to Latin firms. Thus, more studies in Latin America that deepen the level of knowledge and take into account the specific particularities of countries, legal systems, and markets are still required. As Husted et al. [3] indicate, extrapolating previous results from developed countries to Latin American firms would be counter-productive in terms of voluntary disclosure due to the scarcity of empirical evidence along with its unique contexts.

\subsection{Hypotheses}

According to the previous discussion, boards fulfill ample functions in their interactions with internal and external stakeholders. For instance, they serve as a corporate governance mechanism that enhances transparency, good management practices, and promote a greater balance in the interest of all stakeholders. Regarding this role, we derive our first hypothesis (H1): A greater independence of the board is positively correlated with the extent of ESGD. In addition, we expect diversity, as a characteristic of boards, to help facilitate and improve their ability to solve complex problems, access and empathize with global markets so as to enhance transparency, and good management practices. Thus, we state our second hypothesis (H2): Increased diversity on the board is positively correlated with the extent of ESGD. From a theoretical viewpoint, we conjecture that $\mathrm{H} 1$ and $\mathrm{H} 2$ relate to mechanisms through which ESGD has been evidenced to increase the private and social value of FP $[8,11]$.

Moreover, as professional and institutional investors increase their participation in Latin American markets, information asymmetries prod them to increase their demand for information and, likewise, to increase the quality and level of corporate disclosure. Therefore, we state our third hypothesis (H3): The participation of institutional investors in the ownership of firms is positively correlated with the extent of ESGD. We conjecture that $\mathrm{H} 3$ relates to mechanisms through which ESGD has been reported to reduce the weighted average cost of capital [4-6]. Finally, we hypothesize that under the conjoint presence of information asymmetries, pervasive agency problems, and the presence of controlling economic groups within a firm, high levels of ownership concentration could negatively affect the level of disclosure. Accordingly, the latter motivates our fourth hypothesis (H4): The ownership concentration of firms is negatively correlated with the extent of ESGD. We tend to think that $\mathrm{H} 4$ relates to mechanisms which ESGD has been reported to create social value through firm activity [11].

Altogether, these four hypotheses enhance our comprehension of the ESG disclosure phenomenon shedding some light on the factors that determine the extent of ESGD of listed firms in a Latin American market such as Chile. In addition, they help us to explore some of the mechanisms by which boards contribute to create both private and social value.

\section{Methodology}

\subsection{The Data}

We test our hypotheses using data from the main firms belonging to the General Price Index (IGPA) of the Santiago Stock Exchange (SSE) for the period 2015-2019. By the end of 2016, the market capitalization of the IGPA was MMUSD 208,930, which represented almost $90 \%$ of the total market capitalization of the Chilean stock market. Our dataset approximately represents $70 \%$ of the local market capitalization, and it is free from sur- 
vivorship bias since we considered all the firms included in the index that disclosed ESG indicators during the period of analysis. The IGPA index accurately represents the main market trends since it is formed by the majority of the shares traded on the SSE. It is the oldest on the Chilean market, dating from 1954, and since then it has become one of the main indicators for Chilean stock market activity.

For the construction of the dataset, we use three main data sources. First, for each firm, we gather the financial and stock information of the companies listed on the SSE (www.bolsadesantiago.com accessed on 5 June 2021). Second, we obtain the financial information and the ESGD score indicators from the Bloomberg Terminal (www.bloomberg. com accessed on 5 June 2021). And third, we gather the information about the firms' boards (and their members) from local firms from the Chilean Commission of Financial Markets using web scraping methods (CMF, for its acronym in Spanish. The CMF is the Chilean counterpart of the US Securities and Exchange Commission (www.cmfchile.cl accessed on 5 June 2021).

\subsection{Model}

In our sample, the dependent variable (extent of ESGD) is zero-valued with some frequency. This occurs because many firms do not disclose their ESG performance for the complete period. This occurs since not all firms start their disclosing in the same year. Thus, following Frías-Aceituno et al. [14], to adequately account for the censored nature of our dependent variable, we use a tobit model to describe the relation between the ESGD score $\left(E S G D_{i t}\right)$ and ownership $\left(O_{i t}\right)$, independence $\left(I_{i t}\right)$, diversity $\left(D_{i t}\right)$, and the independence of the internal audits $\left(A_{i t}\right)$. To isolate the correlation of each of our variables of interest with the ESGD score, we follow Duran and Rodrigo [22] and Lavin and Montecinos [18] and control for the size of the firm (ln_assets), profitability (mg_ebitda), efficiency (rotact), leverage (ln_leverage), internationalization (dum_deigint), return (pricetobook), and liquidity (liqbur), which we consider in the vector $x_{i t}$. Thus, the general model we use to study our hypotheses is the following:

$E S G D_{i t}=\alpha+\beta_{1} O_{i t}+\beta_{2} I_{i t}+\beta_{3} D_{i t}+\beta_{4} A_{i t}+\gamma x_{i t}+\sum_{j} \beta_{j} I N D_{i t}+\sum_{k} \beta_{k} Y E A R_{i t}+\varepsilon_{i j t}$

Bloomberg's ESG score $\left(E S G D_{i t}\right)$ measures the extent of a firm's ESGD. This measure ranges from 0.1 to 100, where 0.1 represents cases where minimal ESGD occurs and 100 represents the highest ESGD for each ESG dimension: environmental (E), social (S), and governance $(\mathrm{G})$. Accordingly, the dependent variable $E S G D_{i t}$ is the sum in aggregate terms of the score for firm $i$ during year $t$ for the dimensions $\mathrm{E}, \mathrm{S}$, and G. We impute 0 to our dependent variable when no ESGD occurs. In the previous Section 2.2 we explained the theoretical relation between ESGD and ownership, independence, diversity, and the independence of internal audit. Now, we briefly describe the control variables we use summarized in the vector $x_{i t}$. In_assets $i t$ is the natural logarithm of the total assets of firm $i$ during year $t ; m g \_e b i t d a_{i t}$ is the ebitda (earnings before interest, taxes, depreciation, and amortization) margin of firm $i$ during year $t$; rotact ${ }_{i t}$ quatifies the assets' turnover of firm $i$ during year $t$; ln_leverage $i t$ is the natural logarithm of the financial leverage of firm $i$ during year $t$; $d u m_{-}$degint $_{i t}$ is an indicator variable that takes value 1 if firm $i$ exports during year $t$ and 0 otherwise; pricetobook $k_{i t}$ indicates the price-to- book ratio of firm $i$ during year $t$; and finally, liqbur $r_{i t}$ measures the turnover to market capitalization of firm $i$ during year $t$, thereby representing the stock liquidity.

As independent variables, we include the following variables in our model that capture the dimensions of ownership, independence, diversity, and audit. Ownership is measured by control_12 ${ }_{i t}$, the percentage of property of the 12 major shareholders of firm $i$ during year $t$, and ten_inst $t_{i t}$, which is the percentage of institutional investor property on firm $i$ during year $t$. For the case of independence, we consider pindepdir $r_{i t}$, the percentage of independent directors on the board of firm $i$ during year $t$, and pnonexecdir $r_{i t}$, the percentage of non-executive directors on the board of firm $i$ during year $t$. Diversity is represented by pwomenonboard $i t$, the percentage of women on the board of firm $i$ during year $t$, and 
$p$ femalesexec $_{i t}$, the percentage of female executives of firm $i$ during year $t$. Finally, the audit dimension is represented by pinddiraud $d_{i t}$ that is the percentage of independent directors on the audit committee of firm $i$ during year $t$, and pinddircom $p_{i t}$, the percentage of independent directors on the compensation committee. All the econometric models are performed by applying clustered standard errors. Table 1 contains descriptive statistics for the dependent and independent variables.

Table 1. Descriptive statistics for the dependent and independent variables.

\begin{tabular}{cccccc}
\hline Variable & P25 & P50 & P75 & Mean & Std. Dev \\
\hline ESGD & 54.92 & 118.21 & 135.61 & 98.50 & 51.42 \\
Total Assets & 1199.8 & 3528.105 & $13,986.6$ & 9858.425 & $12,648.8$ \\
Mg Ebitda & 0.126 & 0.204 & 0.346 & 0.248 & 0.196 \\
Rotact & 0.235 & 0.442 & 0.755 & 0.479 & 0.323 \\
Leverage & 0.727 & 1.106 & 1.941 & 2.545 & 3.369 \\
Degint & 0 & 0 & 1 & 0.567 & 0.496 \\
Pricetobook & 0.907 & 1.483 & 2.281 & 1.904 & 1.865 \\
Liqbur & 0.079 & 0.141 & 0.232 & 0.183 & 0.169 \\
Control_12 & 0.753 & 0.836 & 0.899 & 0.821 & 0.111 \\
Teninst & 0.012 & 0.045 & 0.117 & 0.066 & 0.062 \\
Pindepdir & 0 & 12.50 & 22.220 & 13.820 & 14.716 \\
Pnonexecdir & 100 & 100 & 100 & 96.213 & 16.845 \\
Pwomenonboard & 0 & 0 & 12.5 & 7.436 & 10.664 \\
Pfemalesexec & 0 & 8.33 & 14.29 & 8.906 & 8.623 \\
Pinddiraud & 0 & 0 & 66.67 & 35.112 & 40.146 \\
Pinddircomp & 0 & 20 & 33.33 & 26.029 & 29.923 \\
\hline Notes: This table presents
\end{tabular}

Notes: This table presents descriptive statistics for the total sample of firms.

In the next section, we explain the process through which we determine the model we use to test our hypotheses.

\subsection{Empirical Strategy}

Our empirical strategy rests on three stages. First, we analyze whether independently considered the variables theoretically related to ownership, independence, diversity, and audit affect or not the disclosure of ESG indicators of our sample of firms. Second, we apply nested model tests to study the relevance of these dimensions when they are jointly studied as factors of ESGD. Finally, once we have analyzed the statistical significance of each dimension in a simultaneous way, we continue studying them but in an isolated form. For the latter, we run unrestricted and restricted model tests as robustness tests to identify the most informative variables for each of the four dimensions that theoretically influence the extent of ESGD. By adopting this econometric strategy, we empirically address the fact that we do not have a theoretical criterion to choose between either of the two alternatives that we use to measure our underlying variables of interest in each dimension and their relation to the level of ESGD. Hence, it will be our statistical procedure that will tell us which of the variables we should use to test our hypotheses.

\section{Results and Discussion}

\subsection{General Results}

As indicated in the previous sections, first we econometrically study whether the variables related to ownership, independence, diversity, and audit independently considered influence or not the extent of ESGD of our sample of firms. The idea is to test the significance of each dimension when considered as a single factor of ESGD. As Table 2 shows, not all the dimensions are statistically significant. First, when we study the impact of ownership, we observe that neither the percentage of control of the 12 major shareholders (control_12) nor the participation of institutional investors (ten_inst) has an influence on ESGD. Second, regarding the impact of board independence, we observe that the percentage of non-executive directors (pnonexecdir) is significant and has a positive effect, while the 
percentage of independent directors (pindepdir) has no influence on ESGD. Third, diversity yields similar results. The percentage of female executives (pfemalesexec) does not affect ESGD, but the impact of the percentage of women on a board (pwomenonboard) is highly significant as an ESGD factor. Finally, the audit dimension shows that the percentage of independent directors on the audit committee (pinddiraud) has no effect, and there is no evidence of the influence of the percentage of independent directors on the compensation committee (pinddircomp). In general, the results of Tables 2 and 3 show that specific attributes of the board such as diversity and independence exert a positive effect on the ESGD indicators of Chilean listed firms when they are considered independently. Furthermore, Tables 2 and 3 indicate that there is no evidence of the influence of the dimensions of ownership and audit on the extent of ESGD.

Table 2. Factors of ESG disclosure score.

\begin{tabular}{|c|c|c|c|c|c|c|c|c|}
\hline \multirow{2}{*}{$\begin{array}{l}\text { Independent Variables } \\
\text { and Controls }\end{array}$} & \multicolumn{4}{|c|}{ Ownership } & \multicolumn{4}{|c|}{ Independence } \\
\hline & (1) & (2) & (3) & (4) & (5) & (6) & (7) & (8) \\
\hline \multirow[t]{2}{*}{ ln_assets } & $14.78^{* *}$ & $24.02 * * *$ & $14.48^{* *}$ & $23.78^{* * *}$ & 14.99 * & $19.47^{* * *}$ & $14.16^{*}$ & $18.11^{* * *}$ \\
\hline & $(0.018)$ & $(0.001)$ & $(0.017)$ & $(0.001)$ & $(0.052)$ & $(0.003)$ & $(0.063)$ & $(0.003)$ \\
\hline \multirow[t]{2}{*}{ mg_ebitda } & $80.36^{*}$ & $100.8^{* *}$ & 87.04 * & $115.2^{* * *}$ & $78.81 *$ & $100.56^{* * *}$ & $81.56^{* *}$ & $111.29^{* * *}$ \\
\hline & $(0.081)$ & $(0.024)$ & $(0.056)$ & $(0.006)$ & $(0.067)$ & $(0.009)$ & $(0.038)$ & $(0.001)$ \\
\hline \multirow[t]{2}{*}{ rotact } & 29.12 & 24.13 & 29.41 & 27.14 & 32.94 & $34.97^{*}$ & 32.88 & $37.17^{* *}$ \\
\hline & $(0.368)$ & $(0.333)$ & $(0.344)$ & $(0.244)$ & $(0.312)$ & $(0.091)$ & $(0.284)$ & $(0.047)$ \\
\hline \multirow[t]{2}{*}{ ln_leverage } & -6.488 & -2.698 & -6.332 & -3.138 & -11.86 & -7.71 & -11.167 & -7.67 \\
\hline & $(0.552)$ & $(0.755)$ & $(0.559)$ & $(0.717)$ & $(0.268)$ & $(0.335)$ & $(0.285)$ & $(0.333)$ \\
\hline \multirow[t]{2}{*}{ dum_degint } & 27.94 & -10.57 & 30.32 & -6.591 & 23.35 & -3.81 & 25.62 & -0.78 \\
\hline & $(0.135)$ & $(0.384)$ & $(0.109)$ & $(0.586)$ & $(0.172)$ & $(0.763)$ & $(0.133)$ & $(0.948)$ \\
\hline \multirow[t]{2}{*}{ pricetobook } & -7.492 & $-9.167^{*}$ & -8.301 & $-10.61^{* *}$ & 6.483 & 3.102 & 6.87 & 3.031 \\
\hline & $(0.226)$ & $(0.055)$ & $(0.179)$ & $(0.029)$ & $(0.262)$ & $(0.459)$ & $(0.261)$ & $(0.526)$ \\
\hline \multirow[t]{2}{*}{ liqbur } & $70.89 *$ & 11.76 & 59.28 & -2.539 & 39.420 & -4.588 & 27.69 & -17.45 \\
\hline & $(0.06)$ & $(0.62)$ & $(0.117)$ & $(0.916)$ & $(0.230)$ & $(0.776)$ & $(0.413)$ & $(0.322)$ \\
\hline \multirow[t]{2}{*}{ ten_inst } & 55.9 & 65.77 & 37.09 & 20.28 & & & & \\
\hline & $(0.526)$ & $(0.529)$ & $(0.687)$ & $(0.848)$ & & & & \\
\hline \multirow[t]{2}{*}{ control_12 } & 103.9 & 53.77 & 96.13 & 27.34 & & & & \\
\hline & $(0.207)$ & $(0.432)$ & $(0.239)$ & $(0.69)$ & & & & \\
\hline \multirow[t]{2}{*}{ pnonexecdir } & & & & & $2.442 * * *$ & $2.088^{* * *}$ & $2.532 * * *$ & $2.164^{* * *}$ \\
\hline & & & & & $(0.004)$ & $(0.000)$ & $(0.002)$ & $(0.000)$ \\
\hline \multirow[t]{2}{*}{ pindepdir } & & & & & 0.0006 & 0.432 & -0.101 & 0.296 \\
\hline & & & & & (0.999) & $(0.198)$ & $(0.811)$ & $(0.386)$ \\
\hline \multirow[t]{2}{*}{ _cons } & $-161.9 *$ & $-206.4^{* *}$ & $-173.6^{*}$ & $-201.3^{* *}$ & $-327.28^{* * *}$ & $-334.37^{* * *}$ & $-350.87^{* * *}$ & $-245.7^{*}$ \\
\hline & $(0.096)$ & $(0.021)$ & $(0.070)$ & $(0.025)$ & $(0.001)$ & $(0.000)$ & $(0.000)$ & $(0.082)$ \\
\hline$N$ & 178 & 178 & 178 & 178 & 178 & 178 & 178 & 178 \\
\hline Pseudo $R^{2}$ & 0.0382 & 0.0989 & 0.0443 & 0.1117 & 0.0514 & 0.1237 & 0.0596 & 0.1405 \\
\hline F & 3.226 & 21.64 & 5.329 & 22.69 & 4.48 & 30.31 & 7.09 & 38.92 \\
\hline Prob $>$ F & 0.0012 & 0.000 & 0.000 & 0.000 & 0.000 & 0.000 & 0.000 & 0.000 \\
\hline FE sector & - & yes & - & yes & - & yes & - & yes \\
\hline FE year & - & - & yes & yes & - & - & yes & yes \\
\hline
\end{tabular}


Table 3. Factors of ESG disclosure score.

\begin{tabular}{|c|c|c|c|c|c|c|c|c|}
\hline \multirow{2}{*}{$\begin{array}{l}\text { Independent Variables } \\
\text { and Controls }\end{array}$} & \multicolumn{4}{|c|}{ Diversity } & \multicolumn{4}{|c|}{ Audit } \\
\hline & (9) & (10) & (11) & (12) & (13) & (14) & (15) & (16) \\
\hline \multirow[t]{2}{*}{ ln_assets } & $15.86^{* *}$ & $23.07 * * *$ & $15.35^{* *}$ & $22.46^{* * *}$ & $16.96 * *$ & $22.20 * * *$ & $16.27 * *$ & $22.00 * *$ \\
\hline & $(0.018)$ & $(0.001)$ & $(0.020)$ & $(0.001)$ & $(0.026)$ & $(0.002)$ & $(0.028)$ & $(0.002)$ \\
\hline \multirow[t]{2}{*}{ mg_ebitda } & $82.38 *$ & $110.6^{* *}$ & $86.93^{* *}$ & $121.4^{* * *}$ & 74.85 * & $91.56^{* *}$ & 80.08 * & $103.5^{* *}$ \\
\hline & $(0.068)$ & $(0.011)$ & $(0.048)$ & $(0.003)$ & $(0.086)$ & $(0.035)$ & $(0.062)$ & $(0.011)$ \\
\hline \multirow[t]{2}{*}{ rotact } & 29.44 & 18.19 & 29.34 & 19.94 & 29.74 & 20.58 & 29.27 & 22.01 \\
\hline & $(0.382)$ & $(0.438)$ & $(0.365)$ & $(0.374)$ & $(0.403)$ & $(0.416)$ & $(0.406)$ & $(0.359)$ \\
\hline \multirow[t]{2}{*}{ ln_leverage } & -8.380 & -1.827 & -8.011 & -1.528 & -11.19 & -7.151 & -10.62 & -6.557 \\
\hline & $(0.410)$ & $(0.824)$ & $(0.423)$ & $(0.850)$ & $(0.314)$ & $(0.364)$ & $(0.337)$ & $(0.408)$ \\
\hline \multirow[t]{2}{*}{ dum_degint } & 25.46 & -11.24 & 27.35 & -10.29 & 23.53 & -2.880 & 26.19 & -1.886 \\
\hline & $(0.133)$ & $(0.363)$ & $(0.106)$ & $(0.394)$ & $(0.176)$ & $(0.833)$ & $(0.134)$ & $(0.889)$ \\
\hline \multirow[t]{2}{*}{ pricetobook } & -7.216 & $-10.67^{* *}$ & -7.864 & $-11.98^{* *}$ & -7.287 & $-9.321^{* *}$ & -7.942 & $-10.45^{* *}$ \\
\hline & $(0.212)$ & $(0.024)$ & $(0.170)$ & $(0.018)$ & $(0.168)$ & $(0.041)$ & $(0.137)$ & $(0.025)$ \\
\hline \multirow[t]{2}{*}{ liqbur } & $68.62 *$ & 13.33 & 57.64 & 0.823 & 54.09 & -1.159 & 43.37 & -12.27 \\
\hline & $(0.092)$ & $(0.601)$ & $(0.156)$ & $(0.973)$ & $(0.112)$ & $(0.994)$ & $(0.208)$ & $(0.575)$ \\
\hline \multirow[t]{2}{*}{ pwomenonboard } & $0.916^{* *}$ & $0.985^{* * *}$ & $0.856^{* *}$ & $0.950^{* * *}$ & & & & \\
\hline & $(0.021)$ & $(0.000)$ & $(0.033)$ & $(0.001)$ & & & & \\
\hline \multirow[t]{2}{*}{ pfemalesexec } & 0.233 & -0.227 & 0.264 & -0.170 & & & & \\
\hline & $(0.788)$ & $(0.677)$ & $(0.754)$ & $(0.730)$ & & & & \\
\hline \multirow[t]{2}{*}{ pinddiraud } & & & & & 0.148 & 0.245 & 0.141 & 0.222 \\
\hline & & & & & $(0.448)$ & $(0.105)$ & $(0.470)$ & $(0.147)$ \\
\hline \multirow[t]{2}{*}{ pinddircomp } & & & & & 0.151 & -0.0285 & 0.108 & -0.0235 \\
\hline & & & & & $(0.548)$ & $(0.881)$ & $(0.673)$ & $(0.905)$ \\
\hline \multirow[t]{2}{*}{ _cons } & -87.82 & $-156.1^{* *}$ & $-104.8 *$ & $-173.2^{* *}$ & -90.38 & $-136.8^{* *}$ & -104.7 & $-157.2 * *$ \\
\hline & $(0.178)$ & $(0.034)$ & $(0.090)$ & $(0.011)$ & $(0.212)$ & $(0.047)$ & $(0.129)$ & $(0.014)$ \\
\hline N & 178 & 178 & 178 & 178 & 178 & 178 & 178 & 178 \\
\hline Pseudo $R^{2}$ & 0.038 & 0.1056 & 0.0443 & 0.1191 & 0.0382 & 0.1034 & 0.0449 & 0.1179 \\
\hline $\mathrm{F}$ & 3.481 & 28.03 & 7.332 & 40.33 & 2.491 & 20.66 & 5.093 & 20.66 \\
\hline Prob $>$ F & 0.000 & 0.000 & 0.000 & 0.000 & 0.000 & 0.000 & 0.000 & 0.000 \\
\hline FE sector & - & yes & - & yes & - & yes & - & yes \\
\hline FE year & - & - & yes & yes & - & - & yes & yes \\
\hline
\end{tabular}

$p$-values in parentheses ${ }^{*} p<0.1,^{* *} p<0.05,{ }^{* * *} p<0.01$.

Following our empirical strategy, in Table 4 we advance in the study of the statistical significance of each of the previous dimensions. We consider the four dimensions at an aggregated level and study their statistical significance when we combine them. For this, we run unrestricted and restricted models to determine which of the dimensions represented in Tables 2 and 3 better econometrically explains the disclosure of ESG indicators of our dataset. Table 4 summarizes the results of different estimations that compare the significance of the latter variables under unrestricted models (Column 1) and restricted models (Columns 2-10). In general terms, our main results indicate that the dimensions of audit and ownership are not statistically significant for explaining the ESGD score of the sample of firms. By contrast, the dimensions of independence and diversity are relevant as positive factors of the extent of the ESGD of the firms. Specifically, regarding the audit dimension, nested tests show that only with $p$-values over $40.91 \%$ is this dimension significant (Column 2). We observe similar results respecting the ownership dimension, where only with $p$-values over $62.32 \%$ this dimension will be a relevant factor for the extent of ESGD (Column 5). Conversely, concerning the dimensions of independence and diversity, Table 4 shows that both are highly significant and positive factors of the ESGD score collected by firms (Columns 3 and 4). 
Table 4. Final nested models and ESG disclosure score.

\begin{tabular}{|c|c|c|c|c|c|c|c|c|c|c|}
\hline Independent Variables and Controls & (1) & (2) & (3) & (4) & (5) & (6) & (7) & (8) & (9) & (10) \\
\hline ln_assets & $\begin{array}{c}16.65^{* * *} \\
(0.006)\end{array}$ & $\begin{array}{c}16.19^{* * *} \\
(0.006)\end{array}$ & $\begin{array}{c}17.74^{* * *} \\
(0.005)\end{array}$ & $\begin{array}{c}20.76^{* * *} \\
(0.001)\end{array}$ & $\begin{array}{c}17.74^{* * *} \\
(0.004)\end{array}$ & $\begin{array}{c}22.46^{* * *} \\
(0.002)\end{array}$ & $\begin{array}{c}17.56^{* * *} \\
(0.003)\end{array}$ & $\begin{array}{c}18.19^{* * *} \\
(0.004)\end{array}$ & $\begin{array}{c}21.48^{* * *} \\
(0.001)\end{array}$ & $\begin{array}{c}17.00^{* * *} \\
(0.002)\end{array}$ \\
\hline mg_ebitda & $\begin{array}{c}108.9 * * * \\
(0.001)\end{array}$ & $\begin{array}{c}112.1^{* * *} \\
(0.001)\end{array}$ & $\begin{array}{c}105.5^{* * *} \\
(0.002)\end{array}$ & $\begin{array}{c}104.8^{* * *} \\
(0.010)\end{array}$ & $\begin{array}{c}112.4^{* * *} \\
(0.001)\end{array}$ & $\begin{array}{c}105.3^{* * *} \\
(0.009)\end{array}$ & $\begin{array}{c}117.7^{* * *} \\
(0.000)\end{array}$ & $\begin{array}{c}105.6^{* * *} \\
(0.002)\end{array}$ & $\begin{array}{c}112.0 * * * \\
(0.008)\end{array}$ & $\begin{array}{c}122.7^{* * * *} \\
(0.001)\end{array}$ \\
\hline rotact & $\begin{array}{c}27.44 \\
(0.183)\end{array}$ & $\begin{array}{c}29.68 \\
(0.119)\end{array}$ & $\begin{array}{l}33.86^{*} \\
(0.080)\end{array}$ & $\begin{array}{c}11.65 \\
(0.627)\end{array}$ & $\begin{array}{c}28.86 \\
(0.149)\end{array}$ & $\begin{array}{c}22.28 \\
(0.349)\end{array}$ & $\begin{array}{l}32.30 * \\
(0.085)\end{array}$ & $\begin{array}{l}33.57 * \\
(0.083)\end{array}$ & $\begin{array}{c}14.73 \\
(0.518)\end{array}$ & $\begin{array}{l}32.44 * \\
(0.088)\end{array}$ \\
\hline ln_leverage & $\begin{array}{l}-6.981 \\
(0.349)\end{array}$ & $\begin{array}{l}-5.690 \\
(0.480)\end{array}$ & $\begin{array}{l}-9.413 \\
(0.220)\end{array}$ & $\begin{array}{c}-2.484 \\
(0.754)\end{array}$ & $\begin{array}{l}-7.195 \\
(0.327)\end{array}$ & $\begin{array}{l}-6.360 \\
(0.448)\end{array}$ & $\begin{array}{c}-5.978 \\
(0.441)\end{array}$ & $\begin{array}{l}-8.992 \\
(0.234)\end{array}$ & $\begin{array}{c}0.393 \\
(0.964)\end{array}$ & $\begin{array}{l}-6.018 \\
(0.425)\end{array}$ \\
\hline dum_degint & $\begin{array}{c}-5.424 \\
(0.674)\end{array}$ & $\begin{array}{l}-7.266 \\
(0.542)\end{array}$ & $\begin{array}{c}0.935 \\
(0.946)\end{array}$ & $\begin{array}{l}-10.15 \\
(0.413)\end{array}$ & $\begin{array}{l}-2.979 \\
(0.814)\end{array}$ & $\begin{array}{c}-0.925 \\
(0.944)\end{array}$ & $\begin{array}{c}-4.404 \\
(0.708)\end{array}$ & $\begin{array}{c}0.772 \\
(0.952)\end{array}$ & $\begin{array}{l}-15.54 \\
(0.168)\end{array}$ & $\begin{array}{c}-2.272 \\
(0.796)\end{array}$ \\
\hline pricetobook & $\begin{array}{l}1.522 \\
(0.752)\end{array}$ & $\begin{array}{c}2.160 \\
(0.651)\end{array}$ & $\begin{array}{c}2.931 \\
(0.547)\end{array}$ & $\begin{array}{c}-11.61^{* *} \\
(0.018)\end{array}$ & $\begin{array}{c}0.507 \\
(0.914)\end{array}$ & $\begin{array}{c}-10.81 \\
(0.021)\end{array}$ & $\begin{array}{c}1.129 \\
(0.802)\end{array}$ & $\begin{array}{c}2.492 \\
(0.614)\end{array}$ & $\begin{array}{c}-11.39^{* *} \\
(0.022)\end{array}$ & $\begin{array}{l}1.575 \\
(0.722)\end{array}$ \\
\hline liqbur & $\begin{array}{l}-16.70 \\
(0.351)\end{array}$ & $\begin{array}{l}-11.81 \\
(0.506)\end{array}$ & $\begin{array}{l}-23.26 \\
(0.204)\end{array}$ & $\begin{array}{l}-4.827 \\
(0.833)\end{array}$ & $\begin{array}{l}-17.40 \\
(0.328)\end{array}$ & $\begin{array}{l}-12.00 \\
(0.594)\end{array}$ & $\begin{array}{l}-12.36 \\
(0.470)\end{array}$ & $\begin{array}{l}-22.50 \\
(0.210)\end{array}$ & $\begin{array}{c}3.902 \\
(0.867)\end{array}$ & $\begin{array}{l}-12.45 \\
(0.418)\end{array}$ \\
\hline ten_inst & $\begin{array}{c}45.76 \\
(0.563)\end{array}$ & $\begin{array}{c}56.84 \\
(0.494)\end{array}$ & $\begin{array}{c}6.531 \\
(0.932)\end{array}$ & $\begin{array}{c}43.30 \\
(0.666)\end{array}$ & & $\begin{array}{l}-19.42 \\
(0.848)\end{array}$ & & & $\begin{array}{c}78.16 \\
(0.445)\end{array}$ & \\
\hline control_12 & $\begin{array}{c}2.658 \\
(0.967)\end{array}$ & $\begin{array}{c}7.780 \\
(0.902)\end{array}$ & $\begin{array}{l}-9.895 \\
(0.877)\end{array}$ & $\begin{array}{c}28.98 \\
(0.660)\end{array}$ & & $\begin{array}{c}5.429 \\
(0.934)\end{array}$ & & & $\begin{array}{c}48.04 \\
(0.485)\end{array}$ & \\
\hline pnonexecdir & $\begin{array}{c}2.071^{* * *} \\
(0.000)\end{array}$ & $\begin{array}{c}2.103^{* * *} \\
(0.000)\end{array}$ & $\begin{array}{c}2.141^{* * *} \\
(0.000)\end{array}$ & & $\begin{array}{c}2.042^{* * *} \\
(0.000)\end{array}$ & & $\begin{array}{c}2.078^{* * *} \\
(0.000)\end{array}$ & $\begin{array}{c}2.115^{* * *} \\
(0.000)\end{array}$ & & $\begin{array}{c}2.144^{* * *} \\
(0.000)\end{array}$ \\
\hline pwomenonboard & $\begin{array}{c}0.723 * * \\
(0.012)\end{array}$ & $\begin{array}{c}0.734^{* * *} \\
(0.009)\end{array}$ & & $\begin{array}{c}0.924^{* * *} \\
(0.009)\end{array}$ & $\begin{array}{c}0.670^{* * *} \\
(0.008)\end{array}$ & & $\begin{array}{c}0.674^{* * * *} \\
(0.006)\end{array}$ & & $\begin{array}{c}1.006^{* * *} \\
(0.002)\end{array}$ & $\begin{array}{c}0.712^{* * *} \\
(0.005)\end{array}$ \\
\hline pfemalesexec & $\begin{array}{c}-0.0221 \\
(0.963)\end{array}$ & $\begin{array}{c}-0.0231 \\
(0.961)\end{array}$ & & $\begin{array}{l}-0.238 \\
(0.623)\end{array}$ & $\begin{array}{c}-0.00870 \\
(0.985)\end{array}$ & & $\begin{array}{c}0.00349 \\
(0.994)\end{array}$ & & $\begin{array}{l}-0.243 \\
(0.627)\end{array}$ & \\
\hline pinddiraud & $\begin{array}{l}0.0910 \\
(0.425)\end{array}$ & & $\begin{array}{c}0.112 \\
(0.345)\end{array}$ & $\begin{array}{c}0.184 \\
(0.159)\end{array}$ & $\begin{array}{c}0.107 \\
(0.403)\end{array}$ & $\begin{array}{c}0.227 \\
(0.119)\end{array}$ & & $\begin{array}{c}0.113 \\
(0.382)\end{array}$ & & \\
\hline pinddircomp & $\begin{array}{l}-0.122 \\
(0.424)\end{array}$ & & $\begin{array}{l}-0.114 \\
(0.427)\end{array}$ & $\begin{array}{c}-0.0485 \\
(0.822)\end{array}$ & $\begin{array}{r}-0.123 \\
(0.401)\end{array}$ & $\begin{array}{c}-0.0192 \\
(0.922)\end{array}$ & & $\begin{array}{l}-0.116 \\
(0.414)\end{array}$ & & \\
\hline _cons & $\begin{array}{c}-336.5^{* * *} \\
(0.001)\end{array}$ & $\begin{array}{c}-340.4^{* * *} \\
(0.000)\end{array}$ & $\begin{array}{c}-334.0 * * * \\
(0.001)\end{array}$ & $\begin{array}{c}-183.7^{* *} \\
(0.032)\end{array}$ & $\begin{array}{c}-340.3^{* * *} \\
(0.000)\end{array}$ & $\begin{array}{c}-166.3^{*} \\
(0.051)\end{array}$ & $\begin{array}{c}-342.6^{* * *} \\
(0.000)\end{array}$ & $\begin{array}{c}-345.1^{* * *} \\
(0.000)\end{array}$ & $\begin{array}{c}-211.2^{* *} \\
(0.013)\end{array}$ & $\begin{array}{c}-341.2^{* * *} \\
(0.000)\end{array}$ \\
\hline N & 178 & 178 & 178 & 178 & 178 & 178 & 178 & 178 & 178 & 178 \\
\hline Pseudo $R^{2}$ & 0.1465 & 0.1455 & 0.1418 & 0.1223 & 0.1460 & 0.1152 & 0.1447 & 0.1417 & 0.1201 & 0.1441 \\
\hline $\mathrm{F}$ & 42.27 & 36.87 & 35.70 & 29.44 & 39.02 & 22.62 & 39.62 & 34.73 & 44.57 & 42.04 \\
\hline Prob $>$ F & 0.0000 & 0.0000 & 0.0000 & 0.0000 & 0.0000 & 0.0000 & 0.0000 & 0.0000 & 0.0000 & 0.0000 \\
\hline LR Chi2 & & 1.79 & 8.26 & 42.85 & 0.95 & 55.46 & 3.14 & 8.42 & 46.80 & 4.32 \\
\hline Prob $>$ Chi2 & & 0.4091 & 0.0161 & 0.0000 & 0.6232 & 0.0000 & 0.5351 & 0.0774 & 0.0000 & 0.6339 \\
\hline
\end{tabular}


The evidence presented in Table 4 also indicates that when these dimensions are combined, only those models that include the dimensions of independence and diversity continue to be significant (Columns 8 and 9). As models that test combined significance reveal, only diversity and independence are significant while ownership and audit are not (Columns 6 and 7). Finally, when we isolate the combined effect of the variables pnonexecdir (independence) and pwomanonboard (diversity), we cannot reject the hypothesis that the rest of the variables of the unrestricted model (Column 10) are not significant, since only with a $p$-value greater than $63.39 \%$ those variables have a value other than zero.

In summary, our findings from Tables 2-4 provide two main broad results. First, only two of the four dimensions included in this study as factors of the ESGD of listed firms in Chile are statistically significant when they are considered individually and combined. Second, there is evidence that the dimensions of diversity and independence exert a positive impact on the extent of ESGD of local listed firms. Finally, within the latter dimensions, our results evidence that the variables pnonexecdir and pwomanonboard are positively correlated with the ESGD score of the Chilean listed firms.

As a final step of our empirical strategy, we evaluate the consistency of the previous results through a robustness analysis. The idea is to corroborate that our previous evidence is robust and not due to some particularities in the data during the period 2015-2019 that are not properly controlled by our control variables. For this, we apply two kinds of robustness tests. First, we examine whether each of the dimensions of Tables 2-4, when isolated considered are relevant factors of ESGD score. Also, we test within each dimension which variables are relevant for explaining the extent of ESGD. As Tables 5 and 6 show only the dimensions of independence and diversity are significant individual factors for the ESGD score. Likewise, the results pinpoint that within each dimension, pnonexecdir (Columns 4-6) and pwomenonboard (Columns 7-9) are significant at a $p$-value of 10\%. Likewise, the models depict that neither ownership dimension (Columns 1-3) nor audit (10-12) are statistically significant and that neither of their respective inner variables are relevant factors for explaining the extent of ESGD.

Table 5. Robustness analysis models.

\begin{tabular}{|c|c|c|c|c|c|c|}
\hline \multirow{2}{*}{ Independent Variables and Controls } & \multicolumn{3}{|c|}{ Ownership } & \multicolumn{3}{|c|}{ Independence } \\
\hline & (1) & (2) & (3) & (4) & (5) & (6) \\
\hline ln_assets & $14.78 * *$ & $16.76^{* *}$ & $15.83^{* *}$ & $14.99 * *$ & 14.99 * & $16.91^{* *}$ \\
\hline & $(0.018)$ & $(0.021)$ & $(0.013)$ & $(0.052)$ & $(0.053)$ & $(0.018)$ \\
\hline mg_ebitda & 80.36 * & $85.12 *$ & $88.98^{*}$ & $78.81^{*}$ & $78.82 *$ & $82.52 *$ \\
\hline & $(0.081)$ & $(0.083)$ & $(0.053)$ & $(0.067)$ & $(0.063)$ & $(0.079)$ \\
\hline rotact & 29.12 & 31.94 & 31.95 & 32.94 & 32.94 & 31.72 \\
\hline & $(0.368)$ & $(0.35)$ & $(0.344)$ & $(0.312)$ & $(0.312)$ & $(0.373)$ \\
\hline ln_leverage & -6.488 & -9.219 & -7.329 & -11.86 & -11.86 & -9.763 \\
\hline & $(0.552)$ & $(0.413)$ & $(0.511)$ & $(0.268)$ & $(0.254)$ & $(0.403)$ \\
\hline dum_degint & 27.94 & 26.52 & 29.1 & 23.36 & 23.36 & 25.78 \\
\hline pricetobook & $\begin{array}{l}(0.135) \\
-7.492\end{array}$ & $\begin{array}{l}(0.15) \\
-7.318\end{array}$ & $\begin{array}{c}(0.12) \\
-8.254\end{array}$ & $\begin{array}{c}(0.172) \\
6.483\end{array}$ & $\begin{array}{c}(0.144) \\
6.484\end{array}$ & $\begin{array}{l}(0.180) \\
-7.134\end{array}$ \\
\hline & $(0.226)$ & $(0.229)$ & $\begin{array}{l}-0.204 \\
(0.16)\end{array}$ & $(0.262)$ & $\begin{array}{l}0.404 \\
(0.262)\end{array}$ & $(0.212)$ \\
\hline liqbur & $70.89 *$ & 58.53 & 69.69 * & 39.42 & 39.42 & 57.79 \\
\hline & $(0.06)$ & $(0.144)$ & (0.074) & $(0.230)$ & $(0.243)$ & (0.133) \\
\hline ten_inst & $\begin{array}{c}55.9 \\
(0.526)\end{array}$ & $\begin{array}{l}-4.19 \\
(0.962)\end{array}$ & & & & \\
\hline control_12 & 103.9 & & 85.68 & & & \\
\hline pnonexecdir & $(0.207)$ & & $(0.283)$ & $\begin{array}{c}2.442 * * * \\
(0.004)\end{array}$ & $\begin{array}{c}2.442^{* * *} \\
(0.004)\end{array}$ & \\
\hline pindepdir & & & & 0.000659 & & 0.117 \\
\hline _cons & $-161.9 *$ & -86.05 & -152.8 & $-327.3^{* * *}$ & $-327.3^{* * *}$ & -88.12 \\
\hline & $(0.096)$ & (0.197) & $(0.108)$ & $(0.000)$ & $(0.000)$ & (0.194) \\
\hline$N$ & 178 & 178 & 178 & 178 & 178 & 178 \\
\hline Pseudo $R^{2}$ & 0.0382 & 0.0346 & 0.0376 & 0.0514 & 0.0514 & 0.0347 \\
\hline $\mathrm{F}$ & 3.226 & 2.691 & 3.221 & 4.48 & 4.66 & 2.62 \\
\hline Prob $>F$ & 0.0012 & 0.0082 & 0.0020 & 0.0000 & 0.0000 & 0.0100 \\
\hline LR Chi2 & & 6.38 & 1.02 & & 0.00 & 29.65 \\
\hline Prob > Chi2 & & 0.0116 & 0.3124 & & 0.9979 & 0.000 \\
\hline
\end{tabular}


Table 6. Robustness analysis models.

\begin{tabular}{|c|c|c|c|c|c|c|c|}
\hline \multirow{2}{*}{$\begin{array}{l}\text { Independent Variables } \\
\text { and Controls }\end{array}$} & \multicolumn{3}{|c|}{ Diversity } & \multicolumn{3}{|c|}{ Audit } & \multirow{2}{*}{$\frac{\text { Indep \& Diversity }}{\text { (13) }}$} \\
\hline & (7) & (8) & (9) & (10) & (11) & (12) & \\
\hline ln_assets & $15.86^{* *}$ & $15.59 * *$ & $16.68^{* *}$ & $16.96^{* *}$ & $16.71^{* *}$ & $17.07^{* *}$ & 8.48 \\
\hline & $(0.018)$ & $(0.022)$ & $(0.016)$ & $(0.026)$ & $(0.026)$ & $(0.022)$ & $(0.198)$ \\
\hline mg_ebitda & $82.38^{*}$ & $83.38^{*}$ & $84.46^{*}$ & $74.85 *$ & 75.75 & 79.70 & $80.95 * *$ \\
\hline & $(0.068)$ & $(0.073)$ & $(0.074)$ & $(0.086)$ & $(0.106)$ & $(0.057)$ & $(0.003)$ \\
\hline rotact & 29.44 & 28.50 & 31.66 & 29.74 & 28.59 & 32.22 & 12.10 \\
\hline & $(0.382)$ & $(0.397)$ & $(0.375)$ & $(0.403)$ & $(0.043)$ & $(0.361)$ & $(0.480)$ \\
\hline ln_leverage & -8.380 & -8.034 & -9.165 & -11.19 & -11.89 & -9.153 & -4.97 \\
\hline & $(0.410)$ & $(0.456)$ & $(0.387)$ & $(0.314)$ & $(0.293)$ & $(0.402)$ & $(0.39)$ \\
\hline dum_degint & 25.46 & 26.35 & 26.43 & 23.53 & 25.85 & 22.62 & -11.92 \\
\hline & $(0.133)$ & $(0.118)$ & $(0.133)$ & $(0.176)$ & $(0.141)$ & $(0.212)$ & $(0.11)$ \\
\hline pricetobook & -7.216 & -7.621 & -7.266 & -7.287 & -7.424 & -7.090 & $5.34 *$ \\
\hline liabur & $\begin{array}{l}(0.212) \\
68.62 *\end{array}$ & $\begin{array}{l}(0.174) \\
67.38^{*}\end{array}$ & $\begin{array}{c}(0.226) \\
58.39\end{array}$ & $\begin{array}{c}(0.168) \\
54.09\end{array}$ & $\begin{array}{c}(0.175) \\
48.81\end{array}$ & $\begin{array}{c}(0.187) \\
62.75\end{array}$ & $\begin{array}{c}(0.088) \\
13.62\end{array}$ \\
\hline & $\begin{array}{l}68.02 \\
(0.092)\end{array}$ & $\begin{array}{l}0.30 \\
(0.095)\end{array}$ & $\begin{array}{l}58.39 \\
(0.148)\end{array}$ & $(0.112)$ & $\begin{array}{l}48.81 \\
(0.177)\end{array}$ & $(0.112)$ & $(0.442)$ \\
\hline pnonexecdir & & & & & & & $\begin{array}{c}2.178^{* * * *} \\
(0.000)\end{array}$ \\
\hline pindepdir & & & & & & & \\
\hline pwomenonboard & $\begin{array}{c}0.916^{* *} \\
(0.021)\end{array}$ & $\begin{array}{c}0.882^{* *} \\
(0.042)\end{array}$ & & & & & $\begin{array}{c}0.884^{* * *} \\
(0.000)\end{array}$ \\
\hline pfemalesexec & $\begin{array}{c}0.233 \\
(0.788)\end{array}$ & & $\begin{array}{c}-0.0121 \\
(0.989)\end{array}$ & & & & \\
\hline pinddiraud & & & & $\begin{array}{c}0.148 \\
(0.448)\end{array}$ & $\begin{array}{c}0.198 \\
(0.303)\end{array}$ & & \\
\hline pinddircomp & & & & 0.151 & & 0.231 & \\
\hline dum_djsi & & & & $(0.548)$ & & $(0.351)$ & $\begin{array}{c}35.030^{* * *} \\
(0.000)\end{array}$ \\
\hline dum_adr & & & & & & & 3.422 \\
\hline _cons & -87.82 & -82.69 & -85.35 & -90.38 & -85.69 & -92.64 & $-291.5^{* * *}$ \\
\hline & $(0.178)$ & $(0.207)$ & $(0.195)$ & $(0.212)$ & $(0.231)$ & $(0.186)$ & $(0.000)$ \\
\hline N & 178 & 178 & 178 & 178 & 178 & 178 & 178 \\
\hline Pseudo $R^{2}$ & 0.0383 & 0.0382 & 0.0346 & 0.0374 & 0.0367 & 0.0364 & 0.1552 \\
\hline $\mathrm{F}$ & 3.48 & 3.49 & 2.68 & 2.49 & 2.74 & 2.75 & 73.85 \\
\hline Prob $>F$ & 0.0006 & 0.0009 & 0.0085 & 0.0107 & 0.0071 & 0.0070 & 0.0000 \\
\hline LR Chi2 & & 0.24 & 6.57 & & 1.13 & 1.78 & \\
\hline Prob > Chi2 & & 0.6210 & 0.0104 & & 0.2878 & 0.1824 & \\
\hline
\end{tabular}

The second robustness test consists of studying the significance of the percentage of non-executive directors on the board (pnonexecdir) and the percentage of women on the board (pwomenonboard) as factors of the ESGD score when we incorporate two extra dummy control variables. The first dummy variable is dum_djsi, which takes the value of 1 if firm $\mathrm{i}$ belongs to the Dow Jones Sustainability Chile Index in year $\mathrm{t}$ and 0 otherwise. The idea here is to control for the possible impact on firms when they belong to this stock index. Similarly, the second dummy variable is dum_adr, which equals 1 if the firm i is listed on the NYSE (New York Stock Exchange) as an ADR (American Depositary Receipts) during year $t$ and 0 otherwise. Table 6 -column 13 shows that the results obtained in Table 4-column 10 remain under this extra analysis. In other words, after controlling for the possible impact of the latter robustness variables, our main evidence continues to be significant for explaining the ESGD score of listed firms in Chile.

In summary, our main evidence provides support for $\mathrm{H} 1$ and $\mathrm{H} 2$. Namely, characteristics of the boards such as independence-measured by the percentage of independent directors - and diversity - measured by the percentage of women on the board-are relevant factors that explain the level of disclosure of ESG indicators among Chilean listed firms for the period 2015-2019. Furthermore, the signs of the effects associated with both variables on the ESGD score of the firms are positive, suggesting a direct relationship between the independence and diversity of Chilean boards and the extent of disclosure of ESG indicators. Ultimately, our empirical analysis does not support H3 and H4, namely, 
institutional investors' participation and the participation of independent directors on the audit committees are not significant factors of the disclosure of ESG indicators.

\subsection{Discussion}

Our work closes the gap regarding the extent of ESGD between developed countries and emerging markets with a focus on Latin America. In this sense, we find evidence consistent with the literature that highlights the role of the board of directors as a leading force in disclosing the ESG performance of companies in developed countries [14,52]. It is precisely the consideration of the particular economic, social, and political environment in developing countries that contributes to providing evidence about the mechanisms that drive ESGD in emerging economies. It is well known that the business environment in emerging markets is far from the reality of developed countries. This is particularly the case in Latin America, where boards must deal with the presence of control groups, a high concentration of ownership, the existence of a high level of interlocking, low participation of institutional investors, low stock market liquidity, limited diversity, and in general a business environment where the opacity of the firms is accentuated; all of these issues exacerbate agency problems among the companies' stakeholders.

In this business context, our empirical findings distinguish two key qualities of boards. First, the positive effect of non-executive directors, whose presence encourages the transparency of firms by providing information regarding the ESG impact of their operations. In a business environment where the independence of decision-makers in senior management is influenced by the business vision of the control groups, independent directors help to balance the interests of all stakeholders, and especially those related to aspects of sustainability $[25,52]$. In this sense, our work shows that independent non-executive directors also contribute to a higher level of disclosure of companies' ESG indicators.

Second, the positive effect of diversity on ESGD, specifically through the participation of women on boards, is also a relevant result in the Latin American business context. Although the presence of women at high levels of management and boards of Latin American firms has been increasing in recent years in the region, their presence in Chile still does not approach the participation of male executives and directors, who predominate on most local boards [25]. This is key, because according to the literature, diversity within firms and, in particular, boards of directors, contributes to a better quality of decisionmaking and greater dissemination of information regarding the sustainability of firms and their operations [14], coupled with a broader viewpoint regarding relevant decisional factors [49,50].

The previous point is important in Latin America since the preferences regarding ESGD by the board of directors would be subject to the preferences of the control groups and the corporate ethos of the business leaders of the companies [18]. In the Chilean case, the above would reflect the business history of the current controllers of the companies, who played key roles as managers of the companies that they currently control [25,61-63]. Our results, in line with the literature, provide support for promoting greater inclusion and diversity at the top levels of Latin American boards and management teams as a source of renewal of business paradigms and broadening of the corporate focus on the creation of value to all stakeholders [52].

Notwithstanding the foregoing, we believe it is important to specify that, although our results suggest a positive relationship between independence and diversity in the boards of directors and the degree of ESG disclosure of firms, the underlying mechanisms of such association, as indicated in the literature, suggest the existence of various possible mechanisms. For instance, more diverse firms in terms of ethnicity, gender, ages, and work experiences, for example, are better prepared to attract top talent, improve their customer orientation, employee satisfaction, and better decision-making, among other implications [64]. In this sense, our results suggest that greater presence of non-executive directors jointly with a major number of women on boards goes on the previous path by expanding the extent of business visions considered in the business decision-making, 
contributing in this way, not only to improving the ESG disclosure, but also potentially associated with better corporate results [65], better corporate governance practices [66], and better ESG risk management by firms [67]. Finally, the pseudo- $R^{2}$ scores suggest that future research could consider additional variables-for instance, environmental aspects of firms' decisions-to examine ESG disclosure scores.

\section{Conclusions}

This work studies the impact of ownership structure and board characteristics on the extent of ESG indicators reported by listed firms in a Latin American market. Our main results show that for the 2015-2019 period, the diversity and independence of the board of directors are significant elements to explain the ESGD score obtained by the companies listed in Chile. In particular, our evidence confirms a positive and significant relationship between the ESGD scores of the main local companies and the percentage of women on the firms' board; and a positive and significant correlation between the ESGD score and the percentage of independent directors belonging to the board. On the contrary, we found no evidence of a relation between the ESGD score and the firm's ownership structure and between the ESGD score and the level of independence of the audit committee.

Our results confirm the importance and role that boards of directors play in emerging markets and particularly in Latin America in making strategic decisions for companies. As previously mentioned, the peculiarity of the Latin American context, characterized among other elements by the existence of control groups, interlocking directorates, the opacity of the firms, and agency problems, levers the relevance of our findings in the sense of conferring on the board of directors an active role in promoting the disclosure of ESG indicators of Latin companies, and consequently improving the levels of transparency in the financial market.

Another interesting finding of our study relates to the absence of impact of the ownership structure on the ESGD score of the firms. In particular, it is striking that under the context of the growing importance of the principles of responsible investment (PRI) by institutional investors in Latin America, these investors do not have a significant effect on the disclosure behavior of ESG indicators of Chilean companies where they are shareholders. One conjecture could be related to the fact that it was not until 2015 that the Dow Jones Sustainability Chile Index was launched, an index that gave the country and its investment community the starting point for sustainable investment and concern for ESG aspects of companies.

This research extends the existing literature which shows a relevant influence of boards' features and ownership structure of firms on strategic decisions in both developed and developing markets. Moreover, by considering Chilean listed firms, this study expands the results of past studies that consider the broad particularities of emerging markets to investigate the ESG disclosure behavior of firms. Therefore, this study contributes to the creation of new knowledge in the strand of the literature that has explored the relationship between ESG disclosure with boards' diversity and independence in Latin America. Particularly, our paper empirically analyses the impact of strategic factors such as firm ownership and board features on ESG disclosure. To the best of our knowledge, the latter analysis reduces the gap present in the literature regarding ESG disclosure, since neither ownership, nor board features have yet been considered in previous studies of ESG disclosure of open firms in the region.

Our research has several practical implications. First, our empirical results provide support for firms that want to move towards a greater ESG culture and transparency in their stakeholders' relations by enhancing the diversity and independence of their board of directors. Second, although the evidence found does not support the relevance of institutional participation, the international evidence does. Hence, we conjecture that it is interesting to promote greater participation of these professional investors in the ownership of the firms at the market level. As a result, taking into account their preference for ESG aspects within their investment policies, they will become promoters inside the board of 
directors. Finally, our results support regulators in their task of overseeing the disclosure of non-financial information of firms and the definition of norms related to the appointment of independent directors and their legal duties as representatives of both majority and minority shareholders.

Our study has some limitations. First, Chile is an emerging market with a medium level of financial development, so its individual characteristics lead us to be cautious when generalizing the results of our research to the rest of the countries in the region. Nevertheless, our work contributes empirical evidence regarding the factors of the disclosure of ESG indicators that have been studied in developed countries but whose findings are not directly applicable to firms in emerging countries. Second, as indicated, the drivers towards sustainable investment and ESG aspects of Chilean firms took on special importance as of 2015. Therefore, the context in which this study was carried out is influenced by this greater sensitivity towards ESG aspects present in Chile. For this reason, the extrapolation of these results to countries with a degree of advancement in ESG matters other than the local one will not necessarily be representative of the particular reality of each country. Finally, compared with developed markets, Latin American markets later embraced ESG global tendencies, their primary focus being on governance and financial issues. Accordingly, our data sources are related to this context. Hence, extrapolations of our results to markets where the environmental dimension of ESG is gaining momentum would not be direct.

As possible expansions of our work, we consider the following lines of study. First, it is important to analyze in greater detail the mechanisms associated with the positive impact of diversity on the boards, as measured by the presence of women and the ESGD. Second, the presence of independent directors in a context of firms controlled by economic groups and with high levels of interlocking demands, as in the previous case, a deeper understanding of the possible mechanisms through which it generates a greater disclosure of ESG indicators. A possible conjecture could be that the presence of women on the board not only increases the ability to solve complex problems by complementing the male-dominant competitive vision with a more collaborative approach to problem-solving, but also that social factors and environmental aspects are being incorporated into the decision-making process. Similarly, in the case of independent directors, we hypothesize that they have a sensitivity aimed at including aspects that affect the rest of the stakeholders in the firm's decision-making processes; therefore, their vision is more closely related to ESG aspects.

As this work enhances the comprehension of the factors that influence the ESGD score among Latin American listed firms, we think that certain advancements would be necessary considering the following factors that would improve the general understanding of this phenomenon. First, it is important to extend the sample of firms by incorporating companies from other Latin American markets in order to explore whether these results are generalizable. Second, we believe it is relevant to incorporate firms from industries other than those present in the Chilean market. For example, in Chile, there is a strong presence of firms listed on the stock market linked to financial services, natural resources, and commerce. It is possible that firms from other industries may behave differently in terms of their ESGD behavior. Third, considering that many firms are global players, there are effects that may be similar at the firm level within the same industry but in different countries. We believe that these future research lines will improve current knowledge regarding ESGD as a key factor of transparency and good corporate governance mechanisms among emerging market firms and especially among Latin American firms.

Finally, we believe that in the post-pandemic era of COVID-19, a period that will likely be characterized by higher constraints to financial market access, the management of ESG risks will become a key factor for both firms and investors. For firms searching for long-term viability, the adequate administration of the challenges imposed by ESG criteria constitute an opportunity to enhance visibility and attract the attention of future capital providers. For the case of investors who are hungry for good investment opportunities 
but with known risks and low uncertainty, the ESGD will help them in their duty of value searching among thousands of issuers of shares and debt instruments.

Author Contributions: Both authors contributed equally to the development of this article, specifically in its conceptualization, conceptual framing and hypotheses construction, methodology design, data analysis, and writing-reviewing-editing. All authors have read and agreed to the published version of the manuscript.

Funding: This research received no external funding.

Institutional Review Board Statement: Not applicable.

Informed Consent Statement: Not applicable.

Data Availability Statement: Not applicable.

Acknowledgments: The authors would like to acknowledge the support of the Business School of the Universidad Adolfo Ibáñez.

Conflicts of Interest: The authors declare no conflict of interest.

\section{References}

1. Bower, J.L.; Leonard, H.B.; Paine, L.S. Capitalism at Risk: Rethinking the Role of Business; Harvard Business Review Press: Boston, MA, USA, 2011.

2. Clementino, E.; Perkins, R. How Do Companies Respond to Environmental, Social and Governance (ESG) ratings? Evidence from Italy. J. Bus. Ethics 2020, 171, 379-397. [CrossRef]

3. Husted, B.W.; de Sousa-Filho, J.M. Board structure and environmental, social, and governance disclosure in Latin America. J. Bus. Res. 2019, 102, 220-227. [CrossRef]

4. Reber, B.; Gold, A.; Gold, S. ESG Disclosure and Idiosyncratic Risk in Initial Public Offerings. J. Bus. Ethics 2021, 1, 1-20. [CrossRef]

5. Raimo, N.; Caragnano, A.; Zito, M.; Vitolla, F.; Mariani, M. Extending the benefits of ESG disclosure: The effect on the cost of debt financing. Corp. Soc. Responsib. Environ. Manag. 2021, 28, 1412-1421. [CrossRef]

6. Raimo, N.; de Nuccio, E.; Giakoumelou, A.; Petruzzella, F.; Vitolla, F. Non-financial information and cost of equity capital: An empirical analysis in the food and beverage industry. Br. Food J. 2020, 123, 49-65. [CrossRef]

7. Henisz, W.; Koller, T.; Nuttall, R. Five Ways That ESG Creates Value; The McKinsey Quaterly: Seattle, WA, USA, 2019.

8. Albitar, K.; Hussainey, K.; Kolade, N.; Gerged, A.M. ESG disclosure and firm performance before and after IR: The moderating role of governance mechanisms. Int. J. Account. Inf. Manag. 2020, 28, 429-444. [CrossRef]

9. Cordazzo, M.; Bini, L.; Marzo, G. Does the EU Directive on non-financial information influence the value relevance of ESG disclosure? Italian evidence. Bus. Strategy Environ. 2020, 29, 3470-3483. [CrossRef]

10. Sharma, P.; Panday, P.; Dangwal, R.C. Determinants of environmental, social and corporate governance (ESG) disclosure: A study of Indian companies. Int. J. Discl. Gov. 2020, 17, 208-217. [CrossRef]

11. Alsayegh, M.F.; Rahman, R.A.; Homayoun, S. Corporate Economic, Environmental, and Social Sustainability Performance Transformation through ESG Disclosure. Sustainability 2020, 12, 3910. [CrossRef]

12. Manes-Rossi, F.; Nicolò, G.; Tiron Tudor, A.; Zanellato, G. Drivers of integrated reporting by state-owned enterprises in Europe: A longitudinal analysis. Meditari Account. Res. 2020, 29, 586-616. [CrossRef]

13. Vitolla, F.; Raimo, N.; Rubino, M.; Garegnani, G.M. Do cultural differences impact ethical issues? Exploring the relationship between national culture and quality of code of ethics. J. Int. Manag. 2021, 27, 100823. [CrossRef]

14. Frias-Aceituno, J.V.; Rodriguez-Ariza, L.; Garcia-Sanchez, I.M. The role of the board in the dissemination of integrated corporate social reporting. Corp. Soc. Responsib. Environ. Manag. 2013, 20, 219-233. [CrossRef]

15. Harris, M. Firms, Contracts, and Financial Structure. by Oliver Hart. Rev. Financ. Stud. 1996, 9, 1271-1277. [CrossRef] [PubMed]

16. Donnelly, R.; Mulcahy, M. Board structure, ownership, and voluntary disclosure in Ireland. Corp. Gov. Int. Rev. 2008, 16, 416-429. [CrossRef]

17. Vitolla, F.; Raimo, N.; Rubino, M. Board characteristics and integrated reporting quality: An agency theory perspective. Corp. Soc. Responsib. Environ. Manag. 2019, 27, 1152-1163. [CrossRef]

18. Lavin, J.F.; Montecinos-Pearce, A.A. Esg reporting: Empirical analysis of the influence of board heterogeneity from an emerging market. Sustainability 2021, 13, 3090. [CrossRef]

19. La Porta, R.; Lopez-de-SIlanes, F.; Shleifer, A.; Vishny, R.W. Law and Finance. J. Polit. Econ. 1998, 106, 1113-1155. [CrossRef]

20. Fortanier, F.; Kolk, A.; Pinkse, J. Harmonization in CSR Reporting: MNEs and Global CSR Standards. Manag. Int. Rev. 2011, 51, 665-696. [CrossRef]

21. Mervelskemper, L.; Streit, D. Enhancing Market Valuation of ESG Performance: Is Integrated Reporting Keeping its Promise? Bus. Strategy Environ. 2017, 26, 536-549. [CrossRef] 
22. Duran, I.J.; Rodrigo, P. Why do firms in emerging markets report? A stakeholder theory approach to study the determinants of non-financial disclosure in Latin America. Sustainability 2018, 10, 3111. [CrossRef]

23. Manes-Rossi, F.; Tiron-Tudor, A.; Nicolò, G.; Zanellato, G. Ensuring more sustainable reporting in Europe using non-financial disclosure-de facto and de jure evidence. Sustainability 2018, 10, 1162. [CrossRef]

24. Matos, P. ESG and Responsible Institutional Investing around the World a Critical Review; CFA Institute Research Foundation: Charlottesville, VA, USA, 2020.

25. Correa-Garcia, J.A.; Garcia-Benau, M.A.; Garcia-Meca, E. Corporate governance and its implications for sustainability reporting quality in Latin American business groups. J. Clean. Prod. 2020, 260, 121142. [CrossRef]

26. La Porta, R.; Lopez-de-Silanes, F.; Shleifer, A. Corporate Ownership around the World. J. Financ. 1999, 54, 471-517. [CrossRef]

27. La Porta, R.; Lopez-de-Silanes, F.; Shleifer, A.; Vishny, R. Investor protection and corporate valuation. J. Financ. 2002, 57, 1147-1170. [CrossRef]

28. Demirgüç-Kunt, A.; Maksimovic, V. Funding growth in bank-based and market-based financial systems: Evidence from firm-level data. J. Financ. Econ. 2002, 65, 337-363. [CrossRef]

29. Brockman, P.; Chung, D.Y. Investor Protection and Firm Liquidity. J. Financ. 2003, 58, 921-937. [CrossRef]

30. Levine, R. The Legal Environment, Banks, and Long-Run Economic Growth. J. Money Credit Bank. 1998, 30, 596-613. [CrossRef]

31. Choi, J.J.; Jo, H.; Kim, J.; Kim, M.S. Business Groups and Corporate Social Responsibility. J. Bus. Ethics 2018, 153, 931-954. [CrossRef]

32. Beck, T.; Levine, R. Stock markets, banks, and growth: Panel evidence. J. Bank. Financ. 2004, 28, 423-442. [CrossRef]

33. Claessens, S.; Yurtoglu, B.B. Corporate governance in emerging markets: A survey. Emerg. Mark. Rev. 2013, 15, 1-33. [CrossRef]

34. Donelli, M.; Larrain, B.; Francisco Urzúa, I. Ownership dynamics with large shareholders: An empirical analysis. J. Financ. Quant. Anal. 2013, 48, 579-609. [CrossRef]

35. Klapper, L.F.; Love, I. Corporate governance, investor protection, and performance in emerging markets. J. Corp. Financ. 2004, 10, 703-728. [CrossRef]

36. La Porta, R.; Lopez-De-Silanes, F.; Shleifer, A.; Vishny, R.W. Legal determinants of external finance. J. Financ. 1997, 52, 1131-1150. [CrossRef]

37. Le Fort, F. Ownership Structure and Corporate Governance in Latin America. Abante 2005, 8, 55-84.

38. Corporate Governance of Company Groups in Latin America; Corporate Governance; OECD Publishing: Paris, France, 2015; ISBN 9789264240124.

39. Cuevas Mejía, J.J.; Maldonado-García, S.; Escobar-Váquiro, N. Aproximación a los factores que influyen en la divulgación sobre RSC en empresas de América Latina. Cuadernos de Contabilidad 2013, 14, 91-131.

40. Lopez, B.; Fornes, G. Corporate social responsibility in emerging markets: Case studies of Spanish MNCs in Latin America. Eur. Bus. Rev. 2015, 27, 214-230. [CrossRef]

41. Sierra-García, L.; García-Benau, M.A.; Zorio, A. Credibility in Latin America of corporate social responsibility reports. RAE Rev. Adm. Empres. 2014, 54, 28-38. [CrossRef]

42. Ali, W.; Frynas, J.G.; Mahmood, Z. Determinants of Corporate Social Responsibility (CSR) Disclosure in Developed and Developing Countries: A Literature Review. Corp. Soc. Responsib. Environ. Manag. 2017, 24, 273-294. [CrossRef]

43. Ingley, C.B.; Van Der Walt, N.T. Corporate governance, institutional investors and conflicts of interest. Corp. Gov. Int. Rev. 2004, 12, 534-551. [CrossRef]

44. Brennan, N.M.; Solomon, J. Corporate governance, accountability and mechanisms of accountability: An overview. Account. Audit. Account. J. 2008, 21, 885-906. [CrossRef]

45. Lorenzo, J.M.P.; Sánchez, I.M.G.; Gallego-Álvarez, I. Characteristics of the board of directors and information in matters of corporate social responsability. Rev. Esp. Financ. Y Contab. 2009, 38, 107-135. [CrossRef]

46. Prado-Lorenzo, J.M.; Rodríguez-Domínguez, L.; Gallego-Álvarez, I.; García-Sánchez, I.M. Factors influencing the disclosure of greenhouse gas emissions in companies world-wide. Manag. Decis. 2009, 47, 1133-1157. [CrossRef]

47. Jensen, M.C.; Meckling, W.H. Theory of The Firm Manajerial Behaviour, Ageny Cost and Ownership structure. J. Financ. Econ. 1976, 3, 305-360. [CrossRef]

48. Robinson, G.; Dechant, K. Building a business case for diversity. Acad. Manag. Perspect. 1997, 11, 21-31. [CrossRef]

49. Betz, M.; O'Connell, L.; Shepard, J.M. Gender differences in proclivity for unethical behavior. J. Bus. Ethics 1989, 8, 321-324. [CrossRef]

50. Harris, J.R. Ethical Values and Decision Processes of Male and Female Business Students. J. Educ. Bus. 1989, 64, 234-238. [CrossRef]

51. Barako, D.G.; Brown, A.M. Corporate social reporting and board representation: Evidence from the Kenyan banking sector. J. Manag. Gov. 2008, 12, 309-324. [CrossRef]

52. Prado-Lorenzo, J.M.; Garcia-Sanchez, I.M. The Role of the Board of Directors in Disseminating Relevant Information on Greenhouse Gases. J. Bus. Ethics 2010, 97, 391-424. [CrossRef]

53. Ouni, Z.; Ben Mansour, J.; Arfaoui, S. Board/Executive Gender Diversity and Firm Financial Performance in Canada: The Mediating Role of Environmental, Social, and Governance (ESG) Orientation. Sustainability 2020, 12, 8386. [CrossRef]

54. Raimo, N.; Vitolla, F.; Marrone, A.; Rubino, M. The role of ownership structure in integrated reporting policies. Bus. Strategy Environ. 2020, 29, 2238-2250. [CrossRef] 
55. Huafang, X.; Jianguo, Y. Ownership structure, board composition and corporate voluntary disclosure: Evidence from listed companies in China. Manag. Audit. J. 2007, 22, 604-619. [CrossRef]

56. Barako, D.G.; Hancock, P.; Izan, H.Y. Factors influencing voluntary corporate disclosure by Kenyan companies. Corp. Gov. Int. Rev. 2006, 14, 107-125. [CrossRef]

57. Cheng, E.C.M.; Courtenay, S.M. Board composition, regulatory regime and voluntary disclosure. Int. J. Account. 2006, 41, 262-289. [CrossRef]

58. Prado-Lorenzo, J.M.; Gallego-Alvarez, I.; Garcia-Sanchez, I.M. Stakeholder engagement and corporate social responsibility reporting: The ownership structure effect. Corp. Soc. Responsib. Environ. Manag. 2009, 16, 94-107. [CrossRef]

59. Haniffa, R.M.; Cooke, T.E. The impact of culture and governance on corporate social reporting. J. Account. Public Policy 2005, 24, 391-430. [CrossRef]

60. Sánchez, I.M.G.; Domínguez, L.R.; Álvarez, I.G. Corporate governance and strategic information on the internet: A study of Spanish listed companies. Account. Audit. Account. J. 2011, 24, 471-501. [CrossRef]

61. Majluf, N.; Abarca, N.; Rodriguez, D.; Fuentes, L. Governance and ownership structure in chilean economic groups. Abante 1998, 1,111-139.

62. Le Fort, F.; Walker, E. Ownership and capital structure of chilean conglomerates: Facts and hypotheses for governance. Abante 2000, 3, 3-27.

63. Agosin, M.; Pastén, E. Corporate governance in Chile. Doc. Trab. (Banco Cent. Chile) 2003, 209, 1-25.

64. Hunt, V.; Layton, D.; Prince, S. Diversity Matters. McKinsey Q. 2015, 1, 15-29.

65. Baselga-Pascual, L.; Vähämaa, E. Female leadership and bank performance in Latin America. Emerg. Mark. Rev. 2021, $48,100807$. [CrossRef]

66. Briano, G.; Rodríguez-Ariza, L. Corporate governance ratings on listed companies: An institutional perspective in Latin America. Eur. J. Manag. Bus. Econ. 2016, 25, 63-75. [CrossRef]

67. OECD. The Future of Corporate Governance in Capital Markets Following the COVID-19 Crisis; OECD Publishing: Paris, France, 2021. [CrossRef] 